\title{
Site Factors Influence on Herbaceous Understory Diversity in East Texas Pinus palustris savannas
}

\author{
Brooke McCalip ${ }^{1}$, Brian P. Oswald ${ }^{1}$, Kathryn R. Kidd ${ }^{1}$, Yuhui Weng ${ }^{1} \&$ Kenneth W. Farrish ${ }^{1}$ \\ ${ }^{1}$ Division of Environmental Science, Arthur Temple College of Forestry and Agriculture, Stephen F. Austin State \\ University, Nacogdoches, USA \\ Correspondence: Brian P. Oswald, Arthur Temple College of Forestry and Agriculture, Stephen F. Austin State \\ University, PO Box 6109, Nacogdoches, TX 75962, USA. Tel: 1-936-645-7990. E-mail: boswald@sfasu.edu
}

Received: October 15, 2018

Accepted: November 22, 2018 Online Published: December 12, 2018

doi:10.5539/ijb.v11n1p1

URL: https://doi.org/10.5539/ijb.v11n1p1

\begin{abstract}
Longleaf pine (Pinus palustris) savannas were once dominant across the southeastern U.S., including East Texas and parts of western and central Louisiana. The diverse understory associated with these historical savannas may occasionally be seen today, but not often in longleaf pine ecosystems. This project aimed to define east Texas site characteristics that are necessary to support these ecosystems with a dense and diverse herbaceous understory with little to no midstory cover. Fifty-nine plots across three study sites were established to evaluate the influence of overstory cover, basal area, aspect, elevation, and slope on the number of plant genera present. Forest structure and site characteristics had significant effects on the number of plant genera found. The number of genera increased with higher elevation and slope; as elevation increased, there was a decline in basal area and overstory cover, leading to a more diverse, understory layer. In order to re-establish and maintain a diverse, herbaceous understory in longleaf pine savannas, sites with more open canopies and on slopes with the most solar exposure should be given priority, particularly when planting desired understory species.
\end{abstract}

Keywords: Restoration, Longleaf Pine, Diversity

\section{Introduction}

The historical range of longleaf pine (Figure 1) extended from the Atlantic Coast to East Texas (Mohr \& Roth, 1897 ) and contained over 37 million hectares of longleaf pine forest (Frost, 1993). Today just over 526,000 hectares of longleaf pine ecosystems remain (Kelly \& Bechtold, 1989), with the majority in a less than desirable state. Longleaf pine (Pinus palustris) was once dominant in East Texas and parts of western and central Louisiana as practically pure stands (Bray, 1904), with a dense herbaceous understory, relatively low midstory cover, and mature longleaf pine trees dominating the overstory. Native understory species have been replaced or reduced by the introduction of exotic plants, fire suppression, intensive forest management activities, and land conversion.

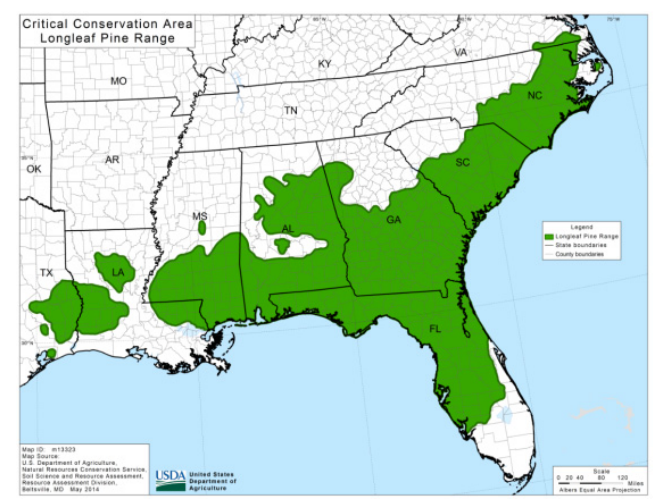

Figure 1. The historic longleaf pine range across the southeastern U.S.. Map taken on June 24, 2018 from the USDA website (Natural Resource Conservation Service) 
Historically, the understory in longleaf pine ecosystems was diverse herbaceous vegetation of grasses and forbs. With a historic fire interval of 2-3 years, woody midstory plants such as sweetgum (Liquidambar styraciflua) were reduced, and herbaceous, pyrophytic plants such as little bluestem (Schizachyrium scoparium), pineywoods dropseed (Sporobolus junceus), wire grass (Aristida spp.), and eastern gammagrass (Tripsacum dactyloides) dominated.

Longleaf pine ecosystems require periodic prescribed fires, in the absence of wildfires, to sustain an understory that will not compete with the longleaf pine overstory, and to support the historic savanna ecotype. Across the entire range, longleaf pine forests historically occurred on different landforms ranging from well-drained, xeric sandhills and rocky mountainous regions to poorly-drained flatwoods (Boyer, 1990), each supporting unique understory communities.

The overall goal of this project was to evaluate east Texas sites that historically supported longleaf pine ecosystems to determine understory vegetation associations based on site factors. Specific objectives of this study were to (i) correlate understory vegetation with overstory cover, basal area, and site parameters, and (ii) identify what site conditions are needed for specific herbaceous vegetation in longleaf pine ecosystems in East Texas.

\section{Material and Methods}

\subsection{Study Sites}

This study was conducted within the Boykin Springs area of the Angelina National Forest $\left(31.05186^{\circ} \mathrm{N}\right.$, $94.26804^{\circ} \mathrm{W}$ ) near Zavalla, Texas, with a humid and subtropical climate (McWhorter, 2005). Boykin Springs is located on the Catahoula geologic formation, and the area is characterized by hot summers (mean daily high of 34 ${ }^{\circ} \mathrm{C}$ in July) with mild winters and an average low temperature of $2^{\circ} \mathrm{C}$ in January. Mean annual rainfall for the study area is $134 \mathrm{~cm}$ with December and May being the wettest with both months having a mean monthly rainfall of $14.2 \mathrm{~cm}$. The drier months, August and October, have a mean monthly rainfall of approximately $9.1 \mathrm{~cm}$ (Oswald et al., 2014).

\subsection{Data Collection}

Fifty-nine plots were located in three study sites (A, B, and C) that differed in soil series, elevation, basal area, and overstory cover which would influence understory plant species composition (Table 1). Locations were chosen "subjectively but without preconceived bias" (Mueller-Dombois \& Ellenberg, 1974) by establishing plots in suitable understory chosen based on visual affirmation of a diverse herbaceous understory with few midstory trees or shrubs, but not all plots were located in areas with these conditions as some plots were located within longleaf pine ecosystems but with more midstory cover. Site A (Figure 2) was burned approximately three months prior to sampling under nesting colonies of red-cockaded woodpeckers. Sites B and C were potential suitable areas that were not currently in the desired forest condition.

Table 1. Study sites with mean vegetative parameters, elevation, and slope

\begin{tabular}{lcccccccc}
\hline Study & $\begin{array}{c}\text { Number of } \\
\text { Species per }\end{array}$ & $\begin{array}{c}\text { Grass } \\
\text { Cover } \\
(\%)\end{array}$ & $\begin{array}{c}\text { Tree Seedling } \\
\text { Cover (\%) }\end{array}$ & $\begin{array}{c}\text { Shrub/Forb } \\
\text { Cover (\%) }\end{array}$ & $\begin{array}{c}\text { Basal Area } \\
\left(\mathrm{ft}^{2} / \text { acre) }\right.\end{array}$ & $\begin{array}{c}\text { Overstory } \\
\text { Cover (\%) }\end{array}$ & $\begin{array}{c}\text { Elevation } \\
(\mathrm{m})\end{array}$ & $\begin{array}{c}\text { Slope } \\
\left({ }^{\circ}\right)\end{array}$ \\
\hline A & Plot & 35 & 38 & 34 & 86 & 81 & 36.1 & 4.1 \\
B & 20 & 44 & 38 & 31 & 115 & 86 & 31.1 & 3.4 \\
C & 20 & 15 & 36 & 102 & 89 & 22.8 & 1.6 \\
\hline
\end{tabular}

Each $5 \mathrm{~m}$ radius plot was established at least $50 \mathrm{~m}$ from a road and at least $50 \mathrm{~m}$ from other plots with selection based upon visual affirmation of suitable understory vegetative cover for longleaf pine ecosystems (Figure 3). Within each plot, a $1 \mathrm{~m}^{2}$ subplot was randomly placed to estimate the percent cover of understory species by grass, shrub/forbs, and trees. Percent ground cover was visually estimated using Daubenmire (1959) classifications and entered as the mean for that respective class $(2.5,15,37.5,62.5,87.5 \%)$. The shrub/forb coverage included nongraminoid herbaceous vegetation or woody species that may become part of the midstory. Tree classification included species that have the potential to become part of the overstory. In addition, any plant within the plot was identified to genus or species if possible and classified as either native or exotic. Since not all of the plants were identified to species, the number of genera was used to determine richness. Within each plot a randomly placed 5 $\mathrm{m}$ line-intersect transect was established to assess little bluestem abundance. Overstory cover was determined using a spherical densiometer and basal area estimated using a $20 \mathrm{BAF}$ wedge prism. Aspect, elevation, and slope were determined through the application ArcMap version 10.5.1 in ArcGIS for desktop. 


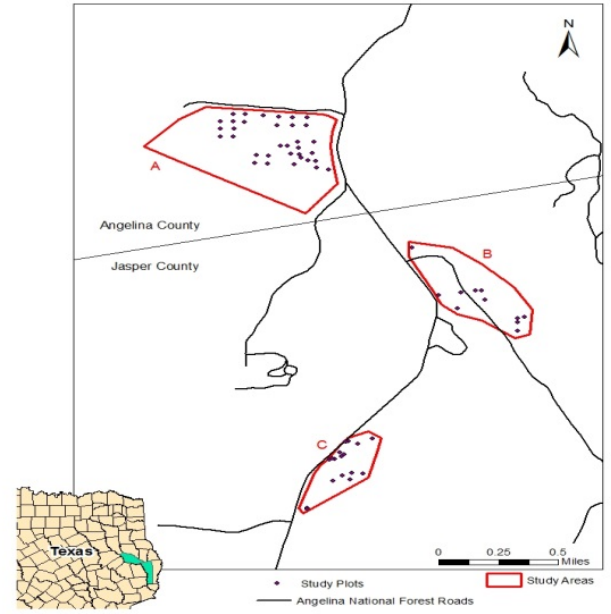

Figure 2. Location of plots across the three sites

(A, B, and C). Data acquired from the ArcGIS

Database at Stephen F. Austin State University and

TNRIS. June 28, 2018

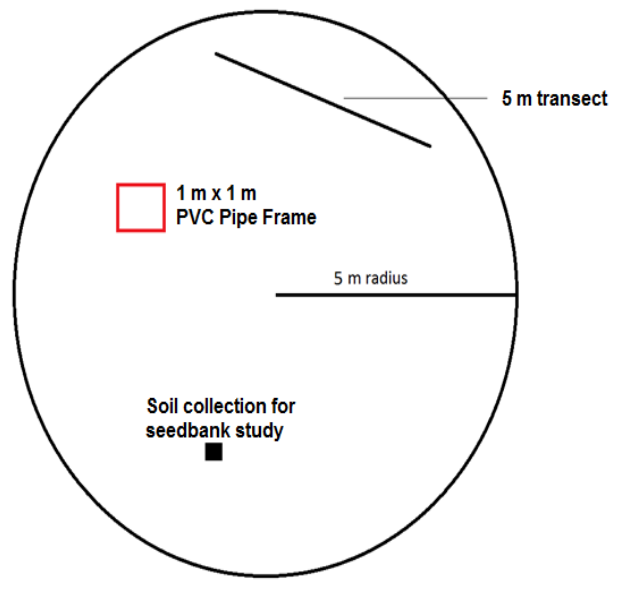

Figure 3. Design of plots located within the Boykin Springs area. Basal area was estimated at the center of each plot

\subsection{Data Analysis}

The Pearson correlation method was used to determine any correlations among the site parameters (basal area, overstory cover, elevation, slope, study site, and aspect) and the number of genera. Analyses of covariance were used to test the impact of the site parameters on independent variables including percent cover of bluestem, grass, tree seedling, percent shrub/forb, and species abundance. Since all dependent variables other than species abundance were expressed as percent, linear modelling was used. Species abundance was recorded as count data, for this trait, a generalized linear model paired with POISSON distribution was used. SAS package (SAS v.9.4 Institute Inc. 2011) was used for all analyses; except where otherwise indicated, the term significant refers to $\operatorname{Pr}<0.10$. A beta diversity index value was calculated in order to determine differences in genera composition between sites using the equation $\beta=\mathrm{c} /(\mathrm{S} 1+\mathrm{S} 2)$ where $\beta$ is equal to the beta diversity index, $\mathrm{c}$ is equal to the genera the two areas have in common, $\mathrm{S} 1$ is equal to the total number of genera in site 1, and S2 is equal to the total number of genera in site 2 .

\section{Results}

Sixty-four different genera were identified across the 59 plots (Table 2). When comparing only two of the sites (Figure 4) beta diversity showed low similarity but was higher when looking at all three sites together. Significant correlations existed between the number of genera and both elevation and slope, as well as between basal area and overstory cover (Table 3). In addition, elevation had a significant correlation with basal area, overstory cover, and slope. Figures 5-11 show the correlations as scatterplots, with weak correlations reflected in Figures 9 and 11. Site was negatively correlated with the number of genera, percent slope and elevation, and a positively correlated with overstory cover.

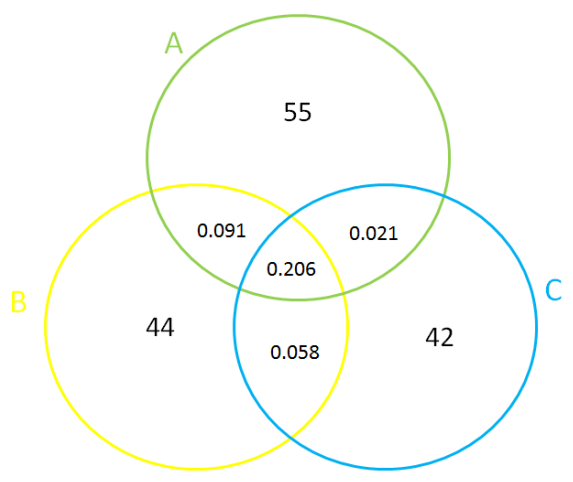

Figure 4 . The total number of genera and the beta diversity index between sites 
Table 2. Genera found near Zavalla, Texas with the respective native status, the number of plots that contained each respective species, the sites where they occurred, and growth form category

\begin{tabular}{|c|c|c|c|c|c|}
\hline & Genus & Number of Plots & Native Status & Site & Growth Form \\
\hline Alophia & & 3 & $\mathrm{~N}$ & $\mathrm{~A}$ & Shrub/Forb \\
\hline Ambrosia & & 36 & $\mathrm{~N}$ & $\mathrm{~A}, \mathrm{~B}, \mathrm{C}$ & Shrub/Forb \\
\hline Ampelopsis & & 2 & $\mathrm{~N}$ & A & Shrub/Forb \\
\hline Andropogon & & 1 & $\mathrm{~N}$ & A & Grass \\
\hline Aristolochia & & 15 & $\mathrm{~N}$ & A & Shrub/Forb \\
\hline Asimina & & 4 & $\mathrm{~N}$ & $\mathrm{C}$ & Tree \\
\hline Berlandiera & & 16 & $\mathrm{~N}$ & $\mathrm{~A}, \mathrm{~B}, \mathrm{C}$ & Shrub/Forb \\
\hline Callicarpa & & 52 & $\mathrm{~N}$ & $\mathrm{~A}, \mathrm{~B}, \mathrm{C}$ & Shrub \\
\hline Campsis & & 2 & $\mathrm{~N}$ & $\mathrm{~B}, \mathrm{C}$ & Shrub/Forb \\
\hline Carex & & 14 & $\mathrm{~N}$ & $\mathrm{~A}, \mathrm{~B}$ & Grass \\
\hline Carya & & 5 & $\mathrm{~N}$ & $\mathrm{~A}, \mathrm{~B}, \mathrm{C}$ & Tree \\
\hline Ceanothus & & 4 & $\mathrm{~N}$ & A & Shrub/Forb \\
\hline Centrosema & & 3 & $\mathrm{~N}$ & $\mathrm{~A}, \mathrm{C}$ & Shrub/Forb \\
\hline Chamaecrista & & 3 & $\mathrm{~N}$ & A & Shrub/Forb \\
\hline Chasmanthium & & 2 & $\mathrm{~N}$ & $\mathrm{C}$ & Grass \\
\hline Cichorium & & 1 & $\mathrm{E}$ & A & Shrub/Forb \\
\hline Cirsium & & 1 & $\mathrm{~N}$ & $\mathrm{C}$ & Shrub/Forb \\
\hline Clitoria & & 14 & $\mathrm{~N}$ & A & Shrub/Forb \\
\hline Cnidoscolus & & 22 & $\mathrm{~N}$ & $\mathrm{~A}, \mathrm{~B}, \mathrm{C}$ & Shrub/Forb \\
\hline Commelina & & 19 & $\mathrm{E}$ & $\mathrm{A}, \mathrm{B}, \mathrm{C}$ & Shrub/Forb \\
\hline Conyza & & 20 & $\mathrm{~N}$ & $\mathrm{~A}, \mathrm{~B}$ & Shrub/Forb \\
\hline Croton & & 50 & $\mathrm{~N}$ & $\mathrm{~A}, \mathrm{~B}, \mathrm{C}$ & Shrub/Forb \\
\hline Cyperus & & 17 & $\mathrm{~N}$ & $\mathrm{~A}, \mathrm{~B}$ & Grass \\
\hline Desmodium & & 52 & $\mathrm{~N}$ & $\mathrm{~A}, \mathrm{~B}, \mathrm{C}$ & Shrub/Forb \\
\hline Dichanthelium & & 46 & $\mathrm{~N}$ & $\mathrm{~A}, \mathrm{~B}, \mathrm{C}$ & Grass \\
\hline Echinacea & & 14 & $\mathrm{~N}$ & A,B & Shrub/Forb \\
\hline Eleocharis & & 1 & $\mathrm{~N}$ & $\mathrm{C}$ & Grass \\
\hline Eragrostis & & 5 & $\mathrm{~N}$ & $\mathrm{~B}, \mathrm{C}$ & Grass \\
\hline Eryngium & & 1 & $\mathrm{~N}$ & B & Shrub/Forb \\
\hline Fragaria & & 1 & $\mathrm{~N}$ & A & Shrub/Forb \\
\hline Galactia & & 16 & $\mathrm{~N}$ & $\mathrm{~A}, \mathrm{~B}, \mathrm{C}$ & Shrub/Forb \\
\hline Gelsemium & & 5 & $\mathrm{~N}$ & $\mathrm{~A}, \mathrm{~B}, \mathrm{C}$ & Shrub/Forb \\
\hline Helianthus & & 18 & $\mathrm{~N}$ & $\mathrm{~A}, \mathrm{~B}$ & Shrub/Forb \\
\hline Hypericum & & 10 & $\mathrm{~N}$ & $\mathrm{~A}, \mathrm{~B}$ & Shrub/Forb \\
\hline Ilex & & 18 & $\mathrm{~N}$ & $\mathrm{~A}, \mathrm{~B}, \mathrm{C}$ & Shrub/Forb \\
\hline Iротоеа & & 6 & $\mathrm{~N}$ & $\mathrm{~A}, \mathrm{C}$ & Shrub/Forb \\
\hline Liatris & & 4 & $\mathrm{~N}$ & A & Shrub/Forb \\
\hline Liquidambar & & 29 & $\mathrm{~N}$ & $\mathrm{~A}, \mathrm{~B}, \mathrm{C}$ & Tree \\
\hline Mimosa & & 45 & $\mathrm{~N}$ & $\mathrm{~A}, \mathrm{~B}, \mathrm{C}$ & Shrub/Forb \\
\hline Morella & & 7 & $\mathrm{~N}$ & $\mathrm{~B}, \mathrm{C}$ & Shrub/Forb \\
\hline Osmunda & & 2 & $\mathrm{~N}$ & $\mathrm{C}$ & Shrub/Forb \\
\hline Oxalis & & 5 & $\mathrm{~N}$ & $\mathrm{~B}, \mathrm{C}$ & Shrub/Forb \\
\hline Parthenocissus & & 9 & $\mathrm{~N}$ & $\mathrm{~B}, \mathrm{C}$ & Shrub/Forb \\
\hline Paspalum & & 12 & $\mathrm{~N}$ & $\mathrm{~A}, \mathrm{~B}, \mathrm{C}$ & Grass \\
\hline Pinus & & 33 & $\mathrm{~N}$ & $\mathrm{~A}, \mathrm{~B}, \mathrm{C}$ & Tree \\
\hline Pityopsis & & 41 & $\mathrm{~N}$ & $\mathrm{~A}, \mathrm{~B}, \mathrm{C}$ & Shrub/Forb \\
\hline Pteridium & & 49 & $\mathrm{~N}$ & $\mathrm{~A}, \mathrm{~B}, \mathrm{C}$ & Shrub/Forb \\
\hline Quercus & & 21 & $\mathrm{~N}$ & $\mathrm{~A}, \mathrm{~B}$ & Tree \\
\hline Rhus & & 18 & $\mathrm{~N}$ & $\mathrm{~A}, \mathrm{~B}, \mathrm{C}$ & Shrub \\
\hline Rubus & & 9 & $\mathrm{~N}$ & $\mathrm{~A}, \mathrm{~B}, \mathrm{C}$ & Shrub/Forb \\
\hline Sassafras & & 37 & $\mathrm{~N}$ & $\mathrm{~A}, \mathrm{~B}, \mathrm{C}$ & Tree \\
\hline Schizachyrium & & 65 & $\mathrm{~N}$ & $\mathrm{~A}, \mathrm{~B}, \mathrm{C}$ & Grass \\
\hline Setaria & & 2 & $\mathrm{~N}$ & $\mathrm{C}$ & Grass \\
\hline Smilax & & 8 & $\mathrm{~N}$ & $\mathrm{~A}, \mathrm{~B}, \mathrm{C}$ & Shrub/Forb \\
\hline Sporobolus & & 16 & $\mathrm{~N}$ & $\mathrm{~A}, \mathrm{~B}$ & Grass \\
\hline Stillingia & & 14 & $\mathrm{~N}$ & A & Shrub/Forb \\
\hline Strophostyles & & 17 & $\mathrm{~N}$ & $\mathrm{~A}, \mathrm{~B}, \mathrm{C}$ & Shrub/Forb \\
\hline Stylisma & & 1 & $\mathrm{~N}$ & A & Shrub/Forb \\
\hline Stylosanthes & & 29 & $\mathrm{~N}$ & $\mathrm{~A}, \mathrm{~B}, \mathrm{C}$ & Shrub/Forb \\
\hline Taraxacum & & 1 & $\mathrm{E}$ & A & Shrub/Forb \\
\hline Tephrosia & & 33 & $\mathrm{~N}$ & $\mathrm{~A}, \mathrm{~B}, \mathrm{C}$ & Shrub/Forb \\
\hline Toxicodendron & & 61 & $\mathrm{~N}$ & $\mathrm{~A}, \mathrm{~B}, \mathrm{C}$ & Shrub/Forb \\
\hline Tradescantia & & 5 & $\mathrm{~N}$ & $\mathrm{~A}, \mathrm{~B}$ & Shrub/Forb \\
\hline Tragia & & 10 & $\mathrm{~N}$ & A & Shrub/Forb \\
\hline Tripsacum & & 33 & $\mathrm{~N}$ & $\mathrm{~A}, \mathrm{~B}, \mathrm{C}$ & Grass \\
\hline Vitis & & 24 & $\mathrm{~N}$ & $\mathrm{~A}, \mathrm{~B}, \mathrm{C}$ & Shrub/Forb \\
\hline Yисcа & & 3 & $\mathrm{~N}$ & A & Shrub/Forb \\
\hline
\end{tabular}


Table 3. Pearson correlation coefficients along with their respective $p$-values. "Prob $>|r|$ under H0: Rho=0" refers to the $\mathrm{p}$-value and indicates the probability of observing the correlation

\begin{tabular}{lcc}
\hline Correlation Variables & Prob $>|\mathrm{r}|$ under H0: Rho $=0$ & Pearson Correlation Coefficient $(\mathrm{R})$ \\
\hline Number of Genera * Elevation & 0.0044 & 0.372 \\
Number of Genera * Slope & 0.0212 & 0.302 \\
Number of Genera * Study Site & $<.0001$ & -0.625 \\
Basal Area * Overstory Cover & 0.0350 & 0.277 \\
Elevation * Slope & 0.0003 & 0.465 \\
Elevation * Basal Area & 0.0918 & -0.225 \\
Elevation * Overstory Cover & 0.0983 & -0.221 \\
Basal Area * Slope & 0.0622 & -0.246 \\
Study Site * Overstory Cover & 0.0269 & 0.291 \\
Study Site * Elevation & $<.0001$ & -0.713 \\
Study Site * Slope & $<.0001$ & -0.500 \\
\hline
\end{tabular}

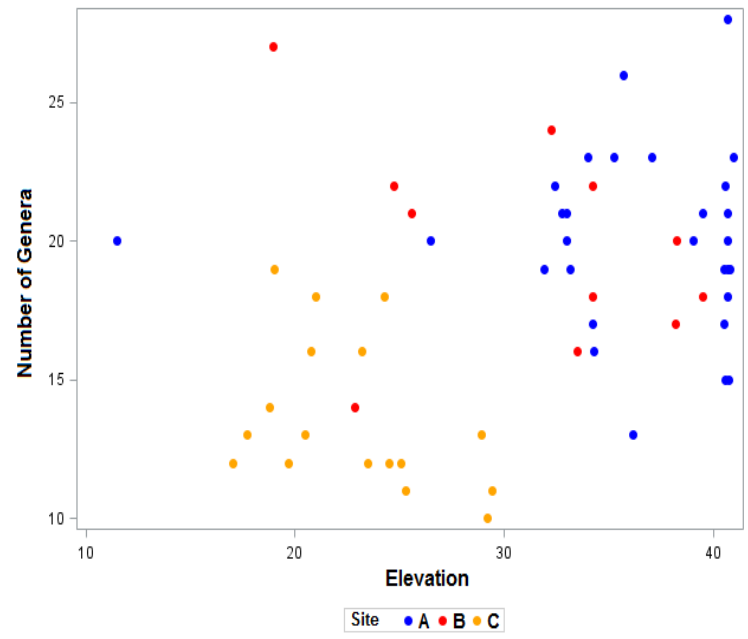

Figure 5. Scatter plot showing a positive correlation between the number of genera $(\mathrm{y})$ and elevation $(\mathrm{x})(\mathrm{R}=0.372)$

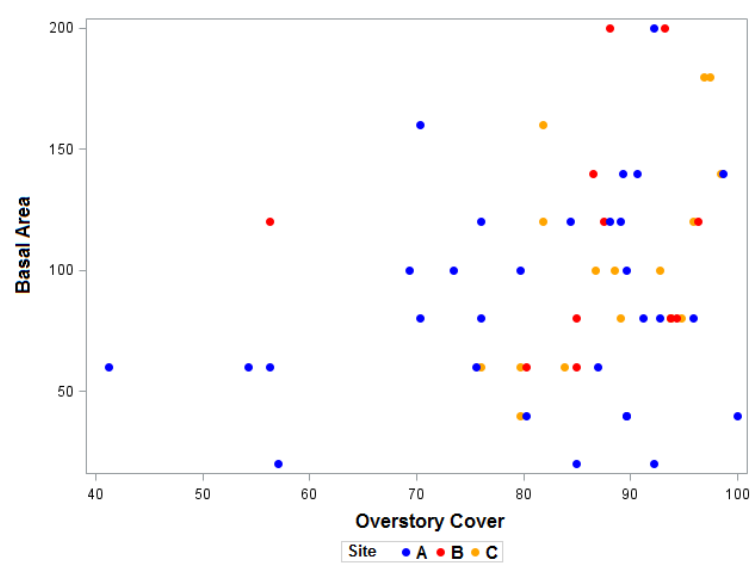

Figure 7. Scatter plot showing a positive correlation between basal area (y) and overstory cover $(\mathrm{x})(\mathrm{R}=0.277)$

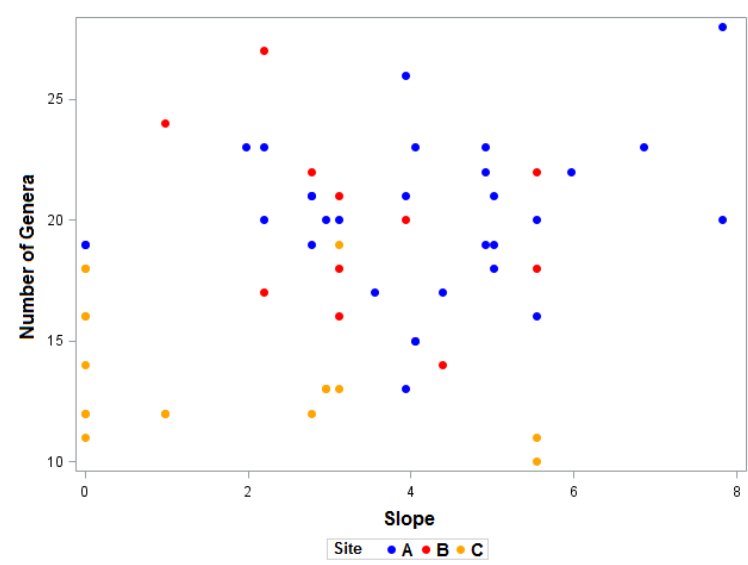

Figure 6. Scatter plot showing a positive correlation between the number of genera $(y)$ and slope $(\mathrm{x})(\mathrm{R}=0.302)$

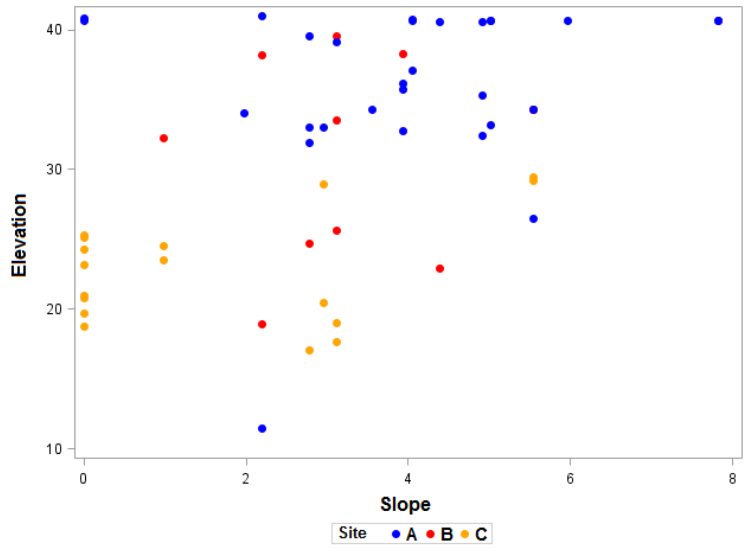

Figure 8. Scatter plot showing a positive correlation between elevation (y) and percent slope (x) $(\mathrm{R}=0.465)$ 


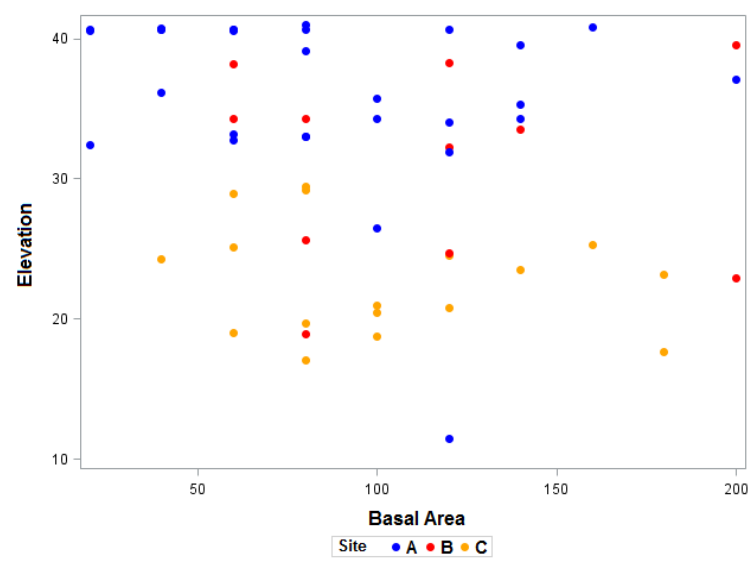

Figure 9. Scatter plot showing a negative correlation between elevation (y) and basal area (x) $(\mathrm{R}=-0.225)$

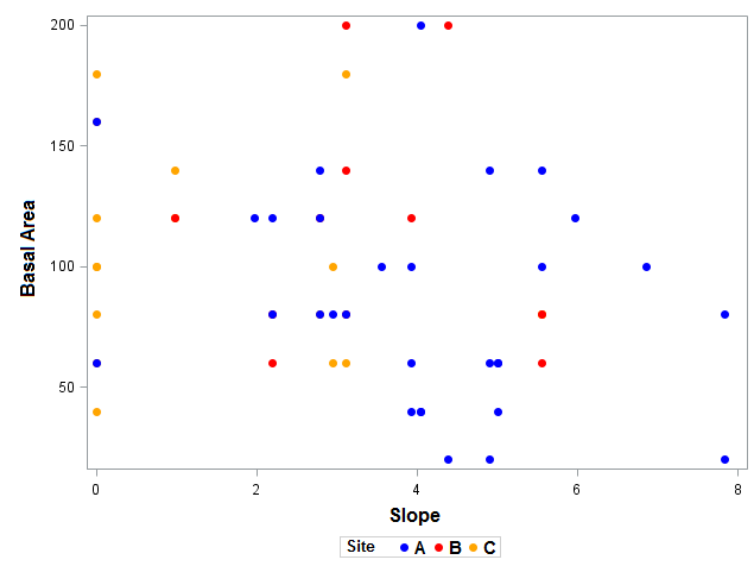

Figure 11. Scatter plot showing a negative correlation between basal area $(\mathrm{y})$ and percent slope $(\mathrm{x})(\mathrm{R}=$ -

$0.246)$

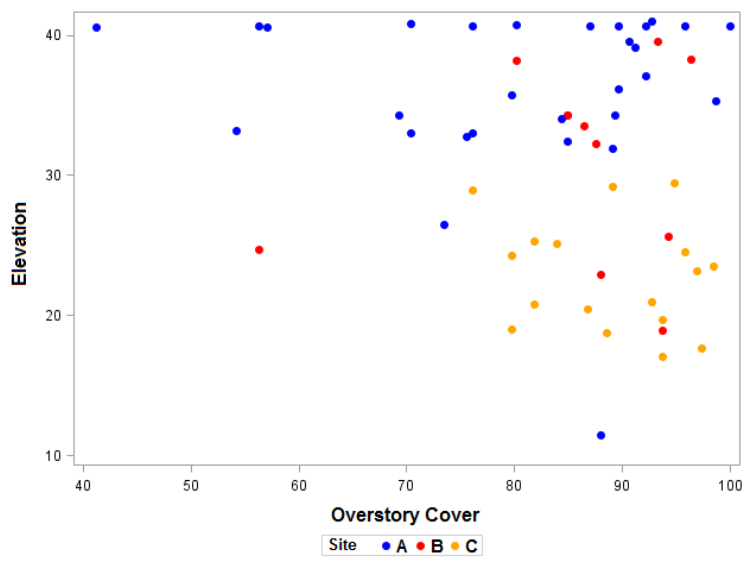

Figure 10. Scatter plot showing a negative correlation between elevation (y) and overstory cover $(\mathrm{x})(\mathrm{R}=-0.221)$

In GLM, the dependent variable 'number of species' found a number of variables which had significant impacts on the number of genera (Table 4). Effects of site variables on the number of species and percent of grass cover, tree seedlings, shrub/forb cover, and bluestem cover are found in Table 5. Elevation and study site significantly influenced not only the number of genera, but also the percent tree seedlings; these seedlings were also negatively correlated to increasing basal area. Site effects on other dependent variables were mostly non-significant, other than effects of elevation on percent shrub/forb cover and overstory cover on percent bluestem cover were significant.

Table 4. GLM results that assumed the POISSON distribution of the number of genera with independent variables of basal area, overstory cover, elevation, slope, and study site

\begin{tabular}{lrrrrrr}
\hline & \multicolumn{7}{c}{ LR Statistics For Type 3 Analysis } & & \\
Source & Num DF & Den DF & F Value & Pr $>$ F & Chi-Square & $\operatorname{Pr}>$ ChiSq \\
\hline Basal Area & 1 & 41 & 0.15 & 0.7022 & 0.15 & 0.7002 \\
Overstory Cover & 1 & 41 & 0.51 & 0.4795 & 0.51 & 0.4754 \\
Elevation & 1 & 41 & 3.57 & 0.0660 & 3.57 & 0.0589 \\
Aspect & 7 & 41 & 0.68 & 0.6906 & 4.74 & 0.6921 \\
Slope & 1 & 41 & 0.19 & 0.6653 & 0.19 & 0.6630 \\
Study Site & 2 & 41 & 14.22 & $<.0001$ & 28.45 & $<.0001$ \\
\hline
\end{tabular}


Table 5. GLM results with dependent variables percent grass cover percent tree seedlings, percent shrub/forb cover and percent bluestem cover and independent variables of basal area, overstory cover, elevation, aspect, slope, and study site

\begin{tabular}{|c|c|c|c|c|c|}
\hline \multicolumn{6}{|c|}{ Percent Grass Cover } \\
\hline Source & $\mathrm{DF}$ & Type III SS & Mean Square & F Value & $\operatorname{Pr}>F$ \\
\hline Basal Area & 1 & 0.0742 & 0.0742 & 0 & 0.992 \\
\hline Overstory Cover & 1 & 95.0111 & 95.0111 & 0.13 & 0.7193 \\
\hline Elevation & 1 & 40.8431 & 40.8431 & 0.06 & 0.8136 \\
\hline Aspect & 7 & 1513.9058 & 216.2723 & 0.3 & 0.9506 \\
\hline Slope & 1 & 10.6994 & 10.6994 & 0.01 & 0.9039 \\
\hline Study Site & 2 & 372.4524 & 186.2262 & 0.26 & 0.7748 \\
\hline \multicolumn{6}{|c|}{ Percent Tree Seedlings } \\
\hline Basal Area & 1 & 428.7461 & 428.7461 & 6.52 & 0.0145 \\
\hline Overstory Cover & 1 & 85.969 & 85.969 & 1.31 & 0.2595 \\
\hline Elevation & 1 & 350.6653 & 350.6653 & 5.33 & 0.0261 \\
\hline Aspect & 7 & 235.7083 & 33.6726 & 0.51 & 0.8201 \\
\hline Slope & 1 & 80.0371 & 80.0371 & 1.22 & 0.2764 \\
\hline Study Site & 2 & 460.7686 & 230.3843 & 3.5 & 0.0394 \\
\hline \multicolumn{6}{|c|}{ Percent Shrub/Forb Cover } \\
\hline Basal Area & 1 & 123.5104 & 123.5104 & 0.35 & 0.5557 \\
\hline Ovestory Cover & 1 & 2.0014 & 2.0014 & 0.01 & 0.9401 \\
\hline Elevation & 1 & 1355.232 & 1355.232 & 3.87 & 0.0559 \\
\hline Aspect & 7 & 2993.3419 & 427.6203 & 1.22 & 0.3131 \\
\hline Slope & 1 & 0.4924 & 0.4924 & 0 & 0.9703 \\
\hline Study Site & 2 & 238.7985 & 119.3992 & 0.34 & 0.7129 \\
\hline \multicolumn{6}{|c|}{ Percent Bluestem Cover } \\
\hline Basal Area & 1 & 18.1531 & 18.1531 & 0.08 & 0.7729 \\
\hline Overstory Cover & 1 & 1015.2624 & 1015.2624 & 4.73 & 0.0365 \\
\hline Elevation & 1 & 27.5355 & 27.5355 & 0.13 & 0.7224 \\
\hline Aspect & 7 & 624.4102 & 89.2015 & 0.42 & 0.886 \\
\hline Slope & 1 & 15.1199 & 15.1199 & 0.07 & 0.7923 \\
\hline Study Site & 2 & 288.3691 & 144.1846 & 0.67 & 0.5173 \\
\hline
\end{tabular}

\section{Discussions}

In mountainous zones, increasing elevation led to peaks in species diversity, accompanied by a decline in overall species richness (Lomolino, 2001). Although East Texas is not a mountainous region, the elevation differences found in our study had an effect on the understory vegetation, as an increase in elevation led to a decrease in overstory cover and basal area, with an associated increase in understory cover. Possible reasons include soil differences found on the upper slopes and ridges than those found on lower slopes. Since slope was negatively correlated with basal area, there most likely was also greater light availability reaching the forest floor (Barbier et al., 2008.) Since herbaceous species respond to slight changes in soil moisture, this relationship might indicate soil moisture conditions associated with elevation and slope (Stromberg et al., 1996). The significant correlation between basal area and overstory cover indicated the higher the basal area the higher the overstory cover, which was not surprising as overstory cover and basal area are inherently positively correlated with each other, and often one is used to predict the other (Mitchell \& Popovich, 1996).

Site was correlated with the number of genera, overstory cover, elevation, and slope, as the site had significant effects on the percent cover by tree seedlings, the number of genera, and percent shrub/forb cover. This could primarily be due to recent effects from prescribed burning of site A three months prior to data collection, whereas sites $\mathrm{B}$ and $\mathrm{C}$ were not burned, and tended to have higher amounts of midstory cover. Site A had a denser herbaceous understory cover with more longleaf pine regeneration. Prescribed burning was not only effective in removing or reducing competitive midstory species, in this case it increased the vigor of herbaceous understory species by allowing more sunlight to reach the forest floor as well as potential increase in available soil nutrients (Olson \& Platt, 1995). The number of genera was highest in site A, which had the highest elevation among sites. 
In all cases except for understory species diversity, aspect had a significant impact upon the understory as the aspect and degree of the slope influences sunlight exposure, and in turn vegetative cover.

Percent grass cover was not influenced by basal area, overstory cover, elevation, aspect, slope, or site, but visual observations noted the effects of lower overstory cover on the coverage of grasses. Basal area, elevation, and site had significant effects on the percent cover of tree seedlings. More tree seedlings were present with lower overstory cover as well, which is explained by an increase in available sunlight reaching the forest floor. Site A had had higher elevation, lower basal area and overstory cover, which led to an increase in the number of plant genera. Increased elevation also had significant impact upon the percent coverage of shrubs and/or forbs. However, this interpretation is confounded by the recent fire that occurred on that site.

\section{Conclusion}

The main site factors driving species abundance and presence were elevation and overstory cover. Less tree cover led to more coverage of grasses, and an increase in elevation led to a decrease in basal area and overstory cover. Where there is an overabundance of midstory, thinning these species would allow for increased viability of understory species plantings, either from fire, mechanical, or chemical methods. Little bluestem was present on all plots and is therefore should not be considered a species of concern for reestablishment efforts in the Boykin Springs area. Since pineywoods dropseed was not as abundant as little bluestem, but is a species of interest to the USFS, this species should be prioritized for reestablishment projects in the East Texas area, and should be successful in plantings in more well-drained, open canopy areas.

Prescribed burning is not only effective in removing or reducing competitive midstory species, in this case it allowed more sunlight to reach the forest floor. Important understory species such as little bluestem and pineywoods dropseed are necessary in longleaf pine savannas in order to maintain the fine fuel source for periodic fires to reduce midstory competition. Longleaf pine ecosystems with a two to eight year fire return interval are most effective at producing a dense, diverse herbaceous understory with increases in fire dependent species of grasses such as little bluestem and Pineywoods dropseed (Brockway \& Lewis, 1997).

Management practices of periodic prescribed fire along with plantings of important understory species in areas with open canopy cover on slopes with the most solar exposure will provide longleaf pine savannas with a more dense, diverse herbaceous understory. Periodic prescribed fires are the most effective tool in maintaining longleaf pine savannas and should be used more often as a management tool to effectively reduce woody competition (Brockway et al., 1997; Brockway \& Outcalt, 1999).

\section{Conflict of interests}

The authors declare that there is no conflict of interests regarding the publication of this paper.

\section{References}

Barbier, S., Gosselin, F., \& Balandier, P. (2008). Influence of tree species on understory vegetation diversity and mechanisms involved-A critical review for temperate and boreal forests. Forest Ecology and Management, 254, 1-15.

Boyer, W. D. (1990). Pinus palustris Mill. longleaf pine. Silvics of North America, 1, 405-412.

Bray, W. L. (1904). Forest resources of Texas. Bureau of Forestry-Bulletin, 47, 21-23.

Brockway, D. G., \& Lewis, C. E. (1997). Long-term effects of dormant-season fire on plant community diversity, structure and productivity in a longleaf pine wiregrass ecosystem. Forest Ecology and Management, 96, 167183.

Brockway, D. G., \& Outcalt, K. W. (1999). Restoring longleaf pine wiregrass ecosystems: Hexazinone application enhances effects of prescribed fire. Forest Ecology and Management, 137, 121-138.

Brockway, D. G., Outcalt, K. W., Tomczak, D. J., \& Johnson, E. E. (2005). Restoration of longleaf pine ecosystems. Gen. Tech. Rep. SRS-83. Asheville, NC: U.S. Department of Agriculture, Forest Service, Southern Research Station. In D. G. Brockway, K. W. Outcalt, \& R. N. Wilkins (Eds.), Restoring longleaf pine wiregrass ecosystems: Plant cover, diversity and biomass following low-rate hexazinone application on Florida sandhills (p. 34). Forest Ecology and Management, 103, 159-175.

Daubenmire, R. (1959). A canopy-cover method of vegetation analysis. Northwest Science, 33, 43-46.

Frost, C. C. (1993). Four centuries of changing landscape patterns in the longleaf pine ecosystem. The Longleaf Pine Ecosystem: Ecology, Restoration and Management. Proceedings Tall Timbers Fire Ecology Conference, $18,17-43$. 
Kelly, J. F., \& Bechtold, W. A. (1989). The longleaf pine resource. In R. M. Farrar, \& Jr. USD (Eds.), Proceedings of the Symposium on the Management of longleaf pine. A Forest Service General Technical Report SO-75. Southern Forest Experiment Station, New Orleans, LA.

Lomolino, M. V. (2001). Elevation gradients of species-density: Historical and prospective views. Global Ecology and Biogeography, 10(1), 3-13.

McWhorter, I. V. (2005). Effects of fire exclusion on the longleaf pine ecosystem of upland island wilderness. (Unpublished master's thesis) Arthur Temple College of Forestry and Agriculture. Stephen F. Austin State University. Nacogdoches, Texas, USA.

Mitchell, J. E., \& Popovich, S. J. (1996). Effectiveness of basal area for estimating canopy cover of ponderosa pine. Forest Ecology and Management, 95, 45-51.

Mohr, C. T., \& Roth, F. (1897). The timber pines of the southern United States. United States Department of Agriculture. Division of Forestry, 13, 176.

Mueller-Dombois, D., \& Ellenberg, H. (1974). Aims and methods of vegetation ecology. New York: Wiley.

Olson, M. S., \& Platt, W. J. (1995). Effects of habitat and growing season fires on resprouting of shrubs in longleaf pine savannas. Vegetatio, 119, 101-118.

Oswald, B. P., Bateineh, M. M., McWhorter, I. V., Legg, M. H., \& Unger, D. R. (2014). Fire Exclusion Effects within the Pinus palustris Communities of Upland Island Wilderness, Texas. Southeastern Naturalist, 13(Sp5).

SAS Institute Inc. 2013. Base SAS ${ }^{\circledR} 9.4$ Procedures Guide. Cary, NC: SAS Institute Inc.

Stromberg, J. C., Tiller, R., \& Richter, B. (1996). Effects of groundwater decline on riparian vegetation of semiarid regions: The San Pedro, Arizona. Ecological Applications, 6, 113-131.

\section{Copyrights}

Copyright for this article is retained by the author(s), with first publication rights granted to the journal.

This is an open-access article distributed under the terms and conditions of the Creative Commons Attribution license (http://creativecommons.org/licenses/by/4.0/). 